Situs Jurnal : $\underline{\text { http://ejurnal.stiepancasetia.ac.id/index.php/jieb }}$

Jilid 4 Nomor 3 November 2018

Hal $353-360$

\title{
PENGARUH MARKETING ONLINE TERHADAP KEPUTUSAN PEMBELIAN PADA KONSUMEN B TO B DI UD. HARAPAN MAULINA SEJAHTERA KABUPATEN JOMBANG
}

\section{Marezza Putri Anggreani*}

Abstract: E-marketing is a modern marketing that bringsin business profits of an enterprise, includeget a chance to introduce their products or services to the whole world. This study was conducted to determine the influences of E-marketing on B2B purchasing decisions on hijab business online in UD.Harapan Maulina Sejahtera district Jombang.This study was conducted to determine the influence of E-marketing on purchasing decisions on business B2B online hijab in UD. Harapan Maulina Sejahtera district Jombang. in addition, also to know how much influence and the variables that influence purchasing decisions B2B on hijab online business in UD. Harapan Maulina Sejahtera. The result shows that e-marketing influence purchasing decision simultaneously and partially.

Keywords: e-marketing, Advertising Online, E-Service, purchasing decissions.

Abstrak: Penelitian ini dilakukan untuk mengetahui sejauh mana pengaruh e-marketing terhadap keputusan pembelian B2B pada usaha jilbab online di UD. Harapan Maulina Sejahtera kabupaten Jombang, selain itu juga untuk mengetahui variabel-variabel apa saja yang mempengaruhi keputusan pembelian B2B usaha jilbab online di UD. Harapan Maulina Sejahtera, dan seberapa besar pengaruhnya terhadap keputusan pembelian B2B pada usaha jilbab online di UD. Harapan Maulina Sejahtera. Variabel-variabel yang digunakan dalam penelitian ini adalah advertising online dan E-Service. Jenis penelitian yang digunakan adalah kuantitatif dengan pendekatan kuesioner, populasinya adalah seluruh konsumen B2B pada usaha jilbab online di UD. Hasil penelitian menunjukkan bahwa marketing online berpengaruh terhadap keputusan pembelian konsumen baik secara simultan maupun secara parsial.

Kata kunci : Marketig online, pengiklanan online, pelayanan online, keputusan pembelian

\section{Latar Belakang}

E-marketing menggambarkan usaha-usaha perusahaan untuk menginformasikan, berkomunikasi, mempromosikan, dan menjual produk dan jasanya lewat internet. Menurut Kotler dalam Kurniawan, (2009) teknologi informasi memberikan peranan yang besar dalam aspek pengelolaan bisnis. Salah satu teknologi informasi yang sampai saat ini banyak digunakan oleh masyarakat dunia adalah internet. Adanya internet marketing juga membawa beberapa keuntungan dalam bisnis suatu perusahaan, antara lain kesempatan produk/jasa mereka dikenal seluruh dunia, pelanggan mendapat kesempatan untuk memutuskan apa yang mereka inginkan, dimana, dan kapan saja, menambah kemampuan perusahaan untuk mengidentifikasi pergantian produk dan tren pelanggan serta untuk mengetes nilai usulan atau tanggapan yang baru. 
Menurut Paul dalam Sutejo, (2006), seperti yang dikutip oleh Eid dan Trueman dalam Sutejo, (2006) menyatakan bahwa melalui internet akan semakin dekat menuju pasar sempurna (perfect market) karena informasi yang spontan dan pembeli dapat membandingkan produk / jasa yang tersedia dengan penjual lain di seluruh dunia. Internet Marketing terkait dengan penggunaan website, promosi online pada search engine, iklan banner website, email langsung, link dan semua aktivitas untuk mendapatkan dan membina hubungan dengan konsumen menurut Chaffey Et Al, dalam Nurlitasari (2012).

Proses keputusan konsumen sebagai hasil dari pemaparan iklan secara umum dimulai dari pengenalan kebutuhan, pencarian informasi, evaluasi alternatif dan diakhiri dengan keputusan pembelian dan kepuasan. E-marketing akan membantu tercapainya tujuan perusahaan yaitu meraih keuntungan yang kompetitif, membuka pasar baru dan pembinaan kesetiaan konsumen terhadap perusahaan. Perusahaan yang ingin progressive dalam pengembanganya akan lebih mudah membidik konsumen Business to Business (B2B).

B2B (Business to Business) adalah bentuk kegiatan pemasaran dimana pemasaran dan jual beli terjadi di antara satu unit bisnis dengan unit bisnis lain. Bentuk produk yang diperjual belikan antara perusahaan-perusahaan itu adalah bentuk produk mentah atau setengah jadi, dimana mereka harus diolah terlebih dahulu oleh salah seorang pihak sebelum akhirnya dapat dijual ke pihak konsumen. Contoh dari pemasaran B2B adalah antara perusahaan ban dengan perusahaan atau perkebunan. Ada istilah supplier dalam pemasaran B2B. Supplier atau yang juga dikenal sebagai pemasok barang berguna untuk memasok barang/produk untuk perusahaan kelola sebelum siap pakai. Contoh lainya juga bisa seperti barang yang sudah jadi diperjual-belikan lagi atau direseler kan kepada para reseler-reseler, agen atau distributor yang tersebar tanpa batas.

UD. Harapan Maulina Sejahtera adalah sebuah usaha produksi hijab instan modern yang menggunakan e-marketing dalam periklanan produknya juga melalui internet atau (online advertising) dan dipasarkan secara delivery order. UD. Harapan Maulina Sejahtera juga membidik pasar konsumen B2B yakni menjual produk kepada para agen maupun distributor yang akan memperjualkan lagi produk tersebut. Menurut Atika, (2010) Business to Business atau sering disingkat menjadi B to B melakukan pemasaran dari satu unit bisnis ke unit bisnis lain untuk diolah terlebih dahulu sebelum akhirnya barang ke tangan konsumen untuk digunakan.

Usaha jilbab ini juga sudah menjangkau pasar hampir dari Sabang sampai Merauke dan juga pernah export keluar negeri yakni Malaysia, Prancis, dan Singapore karena UD. Harapan Maulina Sejahtera sangat memperhatikan faktor-faktor yang menunjang keberhasilan usaha jilbab secara online sehingga usaha ini berkembang pesat dalam waktu yang tergolong singkat, dengan e-marketing yang bisa menjangkau tanpa harus repot-repot expansi usaha bahkan hanya dengan expansi usaha secara sederhana dengan memanfaatkan teknologi yang sudah berkembang mengikuti alur globalisasi dengan memperhatikan kepuasan konsumen dari pengaruh variabel e-marketing terhadap keputusan pembelian dalam penelitian ini yakni advertising online dan e-service. Berdasarkan uraian penjelasan di-atas, peneliti mengambil judul "Pengaruh E-marketing terhadap keputusan pembelian pada konsumen B to B di UD. Harapan Maulina Sejahtera kabupaten Jombang". Tujuan penelitian ini adalah untuk:

1. Untuk menganalisis seberapa besar pengaruh online advertising terhadap keputusan pembelian hijab modern rumah Maulina pada konsumen B to B di UD. Harapan Maulina Sejahtera, Jombang.

2. Untuk menganalisis seberapa besar pengaruh e-service terhadap keputusan pembelian hijab modern rumah Maulina pada konsumen B to B di UD. Harapan Maulina Sejahtera, Jombang. 


\section{Kajian Literatur}

Keuntungan yang dapat diberikan dengan adanya penggunaan E-Marketing ini bagi perusahaan menurut Jamal dalam Manuel, (2013) yaitu: 1. Mampu menjangkau berbagai konsumen dalam suatu lingkungan yang belum dipenuhi oleh pesaing. 2. Target adalah konsumen yang telah terbagi ke dalam kelompok dan mengembangkan dialog berkelanjutan. 3. Transaksi binis secara elektronik dan dengan biaya yang rendah. E-mail dan data files dapat dipindahkan kepada konsumen yang terpilih atau semua konsumen dalam hitungan detik. 4 . Jalur proses penjualan langsung dari produsen ke pengguna tanpa harus melewati jalur distribusi klasik. 5. Dapat menambahkan produk untuk dipasarkan secara cepat dan melakukan perubahan dalam rencana penjualan dengan sangat cepat. 6. Dapat melacak kegiatan penjualan yang sudah terjadi, langkah-langkahnya dan hasil yang didapat. 7. Dapat mengawasi pesaing. 8. Menciptakan dialog antara perusahaan dengan konsumen. 9. Dapat mendistribusikan program dan informasi tentang produk melalui E-mail atau file transfer. Perubahan dari orientasi produk kepada orientasi pasar menjadikan perusahaan harus selalu mengikuti perubahan yang terjadi di pasar juga dalam membangun hubungan kepada konsumen. Layanan elektronik atau (e-service) adalah istilah yang sangat generik, biasanya mengacu pada "Penyediaan layanan melalui Internet, sehingga layanan elektronik bisa juga termasuk perdagangan internet, mungkin juga termasuk layanan non-komersial (online), yang biasanya disediakan oleh pemerintah. (Alexei Pavlichev \& G. David Garson, (2004: 169170); Muhammad Rais \& Nazariah, (2003: 59, 70-71)). Artinya iklan (online advertising) dan layanan elektronik (e-service) juga merupakan bagian dari e-marketing, tujuan akhir dari konsep pemasaran adalah berorientasi pada keputusan pembelian yang menghasilkan kepuasan sehingga pelanggan tetap loyal terhadap jasa yang ditawarkan. Adapun indikator dari variabel online advertising menurut Strauss dalam Sutejo, (2006), alat-alat promosi yang digunakan oleh perusahaan adalah meliputi:

1. Periklanan (Internet Advertising).

2. Hubungan Masyarakat (Public Relation).

3. Promosi Penjualan (Sales Promotion)

Pemasaran Langsung (Direct Marketing) dan Penjualan Personal (Personal Selling). Adapun indikator dari variabel E-service. menurut Lu (2001:6) yang dapat mempengaruhi keputusan pembelian dalam menganalisa produk yang potensial adalah:

1. Mengakses basis pelanggan yang lebih besar.

2. Memperluas jangkauan pasar.

3. Menurunkan penghalang masuk ke pasar baru dan biaya mendapatkan pelanggan baru.

4. Alternatif saluran komunikasi ke pelanggan.

5. Meningkatkan pelayanan kepada pelanggan.

6. Meningkatkan citra perusahaan.

7. Mendapatkan keunggulan kompetitif.

8. Potensi peningkatan pengetahuan pelanggan.

9. Domain layanan elektronik.

Menurut Kotler dan Armstrong, (2008: 239) pemasaran online bisnis ke bisnis (business to business) adalah menggunakan situs web $B 2 B$, e-mail, catalog produk online, jaringan dagang online dan sumber daya online lain untuk menjangkau pelanggan bisnis baru, melayani pelanggan saat ini secara lebih efektif dan meraih efesiensi pembelian dan harga lebih baik. Menurut M. Suyanto dalam Ingge Elissa, (2013), “ Penggolongan E-Commerce yang lazim dilakukan orang ialah berdasar sifat transaksinya. Salah satu tipe dari golongan tersebut adalah Business-to-business (B2B), kebanyakan E-commerce yang diterapkan saat ini merupakan tipe B2B. E-Commerce tipe ini meliputi transaksi IOS yang digambarkan 
transaksi antar organisasi yang dilakukan di Electronic Market. Contohnya, Wal-Mart dengan Warner Lambert.

Menurut (Deavaj et al, 2003), Keputusan membeli secara online dipengaruhi oleh: (1) Efisiensi untuk pencarian (waktu cepat, mudah dalam penggunaan, dan usaha pencarian mudah), (2) value (harga bersaing dan kualitas baik), dan (3) interaksi (informasi, keamanan, load time, dan navigasi). Kemudahan dalam mencari informasi tergantung dari layout halaman web. Jika layout cukup jelas, waktu yang diperlukan untuk searching dapat dipersingkat. Usaha untuk searching lebih mudah. Sehingga efisiensi meningkat.

Berdasarkan hal tersebut diatas, maka dapat diajukan kerangka konseptual penelitian yang ditunjukkan pada gambar 1.

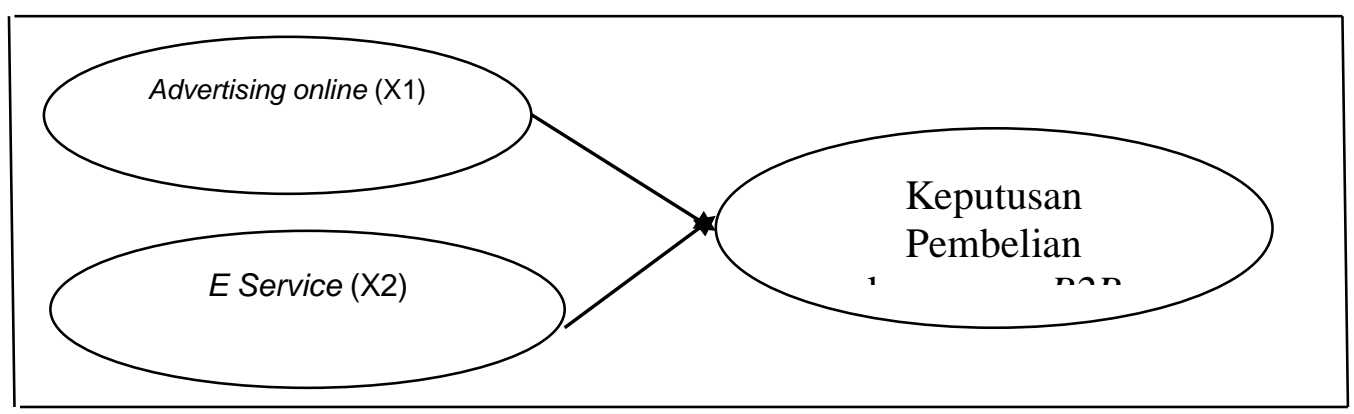

Gambar 1. Model Kerangka Konseptual

Berdasarkan kerangka konseptual pada Gambar 1, maka hipotesis dalam penelitian ini dapat diuraikan sebagai berikut:

1. Advertising online berpengaruh terhadap keputusan pembelian B2B di UD. Harapan Maulina Sejahtera, Jombang.

2. E Service berpengaruh terhadap keputusan pembelian B2B di UD. Harapan Maulina Sejahtera, Jombang.

\section{Metode Penelitian}

Penelitian ini merupakan penelitian survei, yaitu dengan mengambil sampel dari suatu populasi dan menggunakan kuesioner sebagai alat pengumpul data. Yang utama adanya hipotesis yang akan di uji kebenarannya dalam penelitian ini. Jenis penelitian yang dipakai adalah explanatory research, yaitu penelitian yang menjelaskan hubungan kausal antara variabel-variabel dengan melalui pengujian hipotesis.

Penelitian ini dilaksanakan di UD. Harapan Maulina Sejahtera, yang berlokasi di Jl. Wahab Hasbullah No. 82 Jombang. Kegiatan penelitian ini dilakukan pada bulan Januari sampai dengan Maret 2014.

Dalam penyusunan penelitian ini dilakukan di Produksi jilbab online Rumah Maulina Jl. Wahab Hasbullah No. 82 Jombang, populasi dalam penelitian ini adalah jumlah resseler yang telah membeli produk jilbab secara online untuk dipasarkan lagi kepada konsumen (konsumen B2B). Sampel adalah sebagian dari populasi yang karakteristiknya hendak diduga dan dianggap bisa mewakili seluruh populasi. Menurut Arikunto (2005 :123), jika populasi suatu penelitian itu kurang dari 100 maka sampel dapat diambil dari jumlah populasi. Berdasarkan pendapat tersebut, maka jumlah sampel dalam penelitian ini diambil sebanyak 25 orang konsumen B2B. 
Tehnik pengambilan sampel menggunakan metode sensus atau sampling jenuh yaitu metode yang menjelaskan bahwa sampel diambil berdasarkan jumlah populasi (Sugiyono, 2008: 68).

Keabsahan Data pada penelitian ini diuji dengan uji validitas dan uji reliabilitas. Skala yang digunakan oleh peneliti yaitu dengan Skala Likert (Istijanto, 2005: 81). Selanjutnya adalah Uji Asumsi Klasik, yang terdiri

1. Uji Multikolinieritas

2. Uji Autokorelasi

3. Uji Heteroskedastisitas

4. Uji Normalitas

Metode statistik yang digunakan untuk menguji hipotesis dalam penelitian ini adalah regresi liniear berganda (multiple regression) dengan bantuan perangkat lunak SPSS. Untuk menguji hipotesis, maka dalam penelitian in akan dilakukan dengan menggunakan alat uji yaitu:

1. Uji T statistik (Parsial)

2. Uji Dominan

3. Uji Koefisien Determinasi (R2)

\section{Hasil Penelitian dan Pembahasan}

Hasil perhitungan validitas dan reliabilitas untuk variabel kompensasi yang terdiri dari 6 item, kepemimpinan yang terdiri dari 6 item, dan motivasi yang terdiri dari 6 item ini memperlihatkan semua butir instrumen yang digunakan memiliki nilai " $r$ " lebih besar dari 0,3. Menurut Sugiyono (2008: 124), syarat minimum untuk dianggap memenuhi syarat validitas apabila koefisien korelasi $(\mathrm{r})>\mathrm{Uji}$ validitas berarti instrument yang digunakan dapat mengukur apa yang hendak diukur. Validitas yang digunakan dalam penelitian ini menggambarkan kesesuaian sebuah pengukur data dengan apa yang akan diukur (Agusty Ferdinand, 2006). Penguji validitas dalam penelitian ini dengan menghitung korelasi antara skor masing-masing butir pernyataan dengan skor $<0,05$ berarti valid dan apabila Sig. $>0,05$ berarti tidak valid.

Untuk variabel iklan online $\mathrm{X}_{1.1}, \mathrm{X}_{1.2}, \mathrm{X}_{1.3}$ nilai sig ditemukan 0,000 , Untuk variabel layanan elektronik $X_{2.1}$, nilai sig ditemukan $0,000, X_{2.2}$ nilai sig ditemukan $0,006, X_{2.3}$ nilai sig ditemukan 0,009, Untuk variabel keputusan pembelian $\mathrm{B} 2 \mathrm{~B} \mathrm{Y}_{1}$ nilai sig ditemukan 0,003, dan $\mathrm{Y}_{2}, \mathrm{Y}_{3}$ nilai sig ditemukan 0,000 . Berdasarkan hasil uji validitas tersebut dapat diketahui bahwa semua indikator variabel $\mathrm{X}_{1}$ iklan online (advertising online), $\mathrm{X}_{2}$ layanan elektronik ( $e$ service), dan Y keputusan pembelian dinyatakan valid karena hasil korelasi antara hasil jawaban responden pada tiap item kuesioner dengan skor total didapatkan hasil yang signifikan, yaitu nilai $\mathrm{Sig}<0,05$.

Suatu konstruk atau variabel dikatakan reliabel jika memberikan nilai cronbach Alpha > 0,60 ( Imam Ghozali, 2007). Pada advertising online nilai reliabilitas alpha 0.792 Hasil uji intrumen yang positif dan $>0.6$ dikatakan reliable. Hasil uji nilai alpha 0.792 . Jadi instrument tersebut reli-Service nilai reliabilitas alpha 0.6655. Hasil uji intrumen yang positif dan $>0.6$ dikatakan reliable. Hasil uji nilai alpha 0.665 . Jadi instrument tersebut reliable.

Pada advertising online nilai reliabilitas alpha 0.734 . Hasil uji intrumen yang positif dan > 0.6 dikatakan reliable. Hasil uji nilai alpha 0.734. Jadi instrument tersebut reliable. Dari tabel realibility statistica dapat disimpulkan bahwa semua item-item kuesioner adalah reliable (dapat diandalkan) dan dapat digunakan untuk oleh data selanjutnya yang dilihat dari uji croanbach's alpha yang lebih besar dari standar yang disyaratkan yaitu sebesar 0,6. 
Uji multikolinieritas bertujuan untuk menguji apakah model regresi ditemukan adanya korelasi antara variabel bebas (Ghozali, 2005: 95).

Nilai tolerance menunjukkan tidak ada variabel independen yang memiliki nilai tolerance kurang dari 0,10 yang berarti tidak ada korelasi antar variabel independen. Hasil perhitungan nilai variance inflation factor (VIF) juga menunjukkan hal yang sama, tidak ada satu variabel independen yang memiliki nilai VIF lebih dari 10. Jadi dapat disimpulkan bahwa tidak ada multikolonieritas antar variabel independen dalam model regresi.

Uji bertujuan mendeteksi ada atau tidak adanya korelasi dalam suatu model regresi linear. Berdasarkan hasil analisis regresi sebagaimana tampak pada lampiran didapat nilai Durbin Watson (DW) sebesar 1,730. Sesuai dengan ketentuan uji hipotesis yang menyatakan bahwa tidak terjadi autokorelasi jika $1<\mathrm{DW}<3$ dari hasil uji diatas didapat nilai sebesar $1<$ $1,73<3$.

1. Uji Heteroskedastisitas

Berdasarkan grafik scatterplots ini terlihat titik-titik menyebar secara acak serta tersebar baik di atas maupun di bawah angka 0 pada sumbu Y. Hal ini dapat disimpulkan bahwa tidak terjadi heteroskedastisitas pada model regresi, sehingga model regresi layak dipakai untuk memprediksi iklan online, layanan elektronik terhadap keputusan pembelian B2B.

2. Uji Normalitas

Pengujian normalitas dalam penelitian ini digunakan dengan melihat normal probability plot yang membandingkan distribusi kumulatif dari data sesungguhnya dengan distribusi kumulatif dari data normal. Sedangkan dasar pengambilan keputusan untuk uji normalitas data adalah:

a. Jika data menyebar di sekitar garis diagonal dan mengikuti arah garis diagonal atau grafik histogramnya menunjukkan distribusi normal, maka model regresi memenuhi asumsi normalitas.

b. Jika data menyebar jauh dari diagonal dan/atau tidak mengikuti arah garis diagonal atau grafik histogram tidak menunjukkan distribusi normal, maka model regresi tidak memenuhi asumsi normalitas.

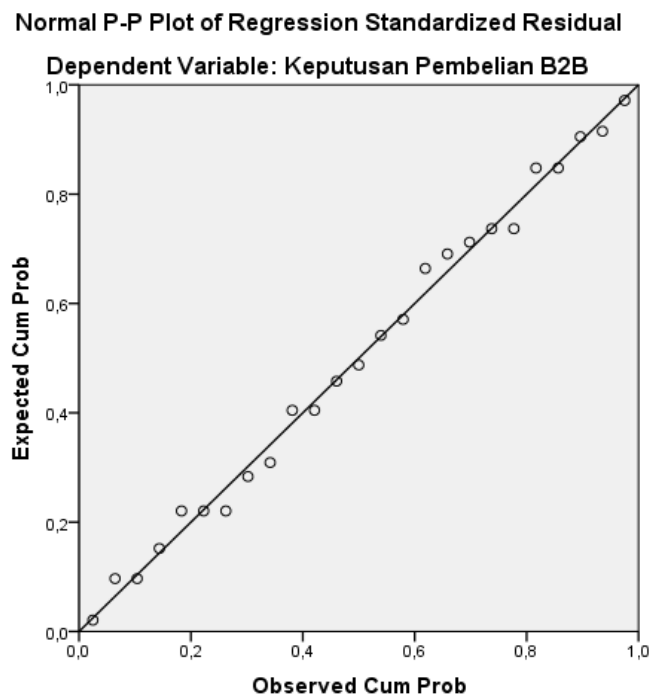

Jika residual berasal dari distribusi normal, maka nilai-nilai sebaran data akan terletak sekitar garis lurus, terlihat bahwa sebaran data pada gambar diatas tersebar hampir pada sumbu normal, maka dapat dikatakan bahwa pernyataan normalitas dapat dipenuhi. 
Analisis hasil uji parsial (uji t) digunakan untuk membuktikan hipotesis kedua. Hasil regresi secara parsial dapat dijelaskan sebagai berikut:

1. Variabel $\mathrm{X}_{1}$ Iklan Online nilai t hitung sebesar 2,091> t tabel 1,708 dengan probabilitas sebesar 0,048. Signifikasi iklan online (advertising online) sebesar 0,048<0,05 maka $\mathrm{H}_{1}$ diterima, yang berarti variabel $\mathrm{X}_{1}$ iklan online (advertising online) berpengaruh secara parsial terhadap variabel $\mathrm{Y}$ keputusan pembelian B2B.

2. Variabel $\mathrm{X}_{2}$ layanan elektronik (E-Service) nilai $\mathrm{t}$ hitung sebesar 3,245> t tabel 1,708 dengan probabilitas sebesar 0,004. Signifikasi Layanan Elektronik (E-Service) sebesar 0,004< 0,05 maka H1 diterima,yang berarti variabel $\mathrm{X}_{2}$ Layanan Elektronik (E-Service) berpengaruh secara parsial terhadap variabel $\mathrm{Y}$ keputusan pembelian B2B.

Nilai koefisien determinasi $\left(\mathrm{R}^{2}\right)$ Berdasarkan tabel model summary, dapat disimpulkan bahwa iklan online dan layanan elektronik sebesar 33,6 \% terhadap keputusan pembelian yang dilihat dari $R$ Square, sedangkan $66,4 \%$ dipengaruhi oleh variabel lain yang tidak diteliti dalam model penelitian ini.

\section{Kesimpulan}

Berdasarkan hasil penelitian dan pembahasan yang telah diuraikan pada bab terdahulu maka peneliti dapat menyimpulkan bahwa:

1. Faktor iklan online (advertising online) (X1) berpengaruh secara parsial terhadap keputusan konsumen B2B (Business to business) (Y) pada UD. Harapan Maulina Sejahtera.

2. Faktor layanan elektronik (E-service) (X2) berpengaruh secara parsial terhadap keputusan konsumen B2B (Business to business) (Y) pada UD. Harapan Maulina Sejahtera.

Berdasarkan kesimpulan diatas, maka peneliti berupaya membantu memberikan solusi dalam kekurangan dan kelemahan pada pihak UD. Harapan Maulina Sejahtera Kabupaten Jombang adalah sebagai berikut:

1. Agar tetap meningkatkan kualitas iklan online, hal ini bisa dilakukan dengan selalu update terhadap arus fashion zaman sekarang, model dan kualitas hijab yang dipasarkan secara online dapat dipahami dan menarik dari gambar atau konten iklan pada advertising online dan,

2. Layanan elektronik juga harus tetap selalu ditingkatkan untuk lebih memuaskan konsumen B2B dalam informasi dan bertransaksi secara online, terutama pelayanan yang harus diperhatikan adalah ketika launching edisi baru pada awal bulan agar tetap selalu intens melayani konsumen dalam transaksi online.

3. Penelitian ini diharapkan dapat mendorong penelitian-penelitian yang lainya, baik dengan penelitian yang sejenis atau dengan data yang lebih luas. Semoga hasil penelitian ini dapat dijadikan pedoman bagi penelitian berikutnya.

\section{DAFTAR PUSTAKA}

Ferdinand, 2006. Metode Penelitian Manajemen: Pedoman Penelitian Untuk Penulisan Skripsi, Tesis dan Disertasi illmu Manajemen. Badan Penerbit Universitas Diponegoro. Semarang.

Ghozali, Imam. (2007). Aplikasi Analisis Multivariat dengan Program SPSS. Badan Penerbit. Universitas Diponegoro, Semarang.

Kotler, Philip dan Garry Armstrong, (2003), Marketing An Introduction Sixth Edition, Upper Saddle River, New Jersey: Prantice Hall. 
Lu, J. (2001). Measuring cost/benefits of e-business applications and customer satisfaction", Proceedings of the 2nd International Web Conference, 29-30 November, Perth, Australia, 139-47

Sugiyono, 2008, Statistika Untuk Penelitian, Cetakan Ketujuh, Bandung: CV. Alfabeta. Sugiyono. 2008. Metode Penelitian Kuantitatif dan Kualitatif. CV. Alfabeta: Bandung.

Sutejo. 2006. Internet Marketing : Konsep dan Persoalan Baru Dunia Pemasaran. Jurnal Manajemen 41-43. www.google.com. Diakses tanggal 8 Februari 2014.

Yohanes Kurniawan. 2009. E-Marketing Sebagai Alat Bantu Dalam Memperluas Pasar. Universitas Bina Nusantara. Jakarta. www.google.com. Diaksestanggal 8 Februari 2014.

Yosan Manuel. 2013. Inovasi Dan Dampak Jasa Iklan Berbasis Elektronik (E-Marketing). Universitas Ma Chung. Malang. www.google.com. Diakses tanggal 9 Februari 2014. 